Here, we look at two articles published in Fruits 12 (10) and (11).

\title{
Citrus Tristeza
}

The first paper, written by A. Comelli, relates to "Citrus Tristeza in French Equatorial Africa (FEA)".

The very first cases of citrus Tristeza detected in Central Africa are reported:

"In 1952, Mr. Pelegrin [French Institute of Research on Tropical Fruits (IFAC)], in bis survey report of a survey on the FEA, mentioned the possible presence of Tristeza in the collection of Brazzaville and recommended carrying out tests before continuing to spread these varieties. We know now that it was already too late.

In 1954, we observed for the first time in Boko... a grapefruit ... affected by Stem pitting...

In 1956, at the time of a second visit to Boko, we brought back photographs of the symptoms observed which were identified as answering the description of Stem pitting...

In June 1957, we observed in a groundnut grower of Madingou very clear symptoms of Tristeza on local acid lime seedlings...

On the station of Loudima (IFAC), several seedlings of Mexican lime presenting the same symptoms at a more marked stage were observed recently... It thus seems well proven that Tristeza exists in Niari...

It is besides likely that Cameroon is also affected, because the same false deficiencies were observed on young grafts at the Nyombé station (IFAC).

Lastly, in Oubangui, we observed typical cases of Stem pitting...

... In Chad, symptoms identical to the false deficiencies were observed... They are strong presumptions for the presence of Tristeza.

A more serious consequence of this situation is the danger that it represents for North Africa... in spite of the screen that the Sahara represents."

\section{Banana Sigatoka disease}

The second paper, written by J. Cuillé and H. Guyot, relates to "The spraying material, its use". We will only reproduce the introduction that replaces this article in the body of work on the control of banana Sigatoka disease, which has marked the life of the French Institute of Research on Tropical Fruits:

"We had shown, in a preceding work, that, during the use of apparatuses with reduced flow, the operator was confronted with two pieces of data of opposing interest:

- to generate a pesticide cloud made up of very small particles that makes it possible to reach a great range, and to ensure an excellent distribution of the pesticide on the leaf.

- to fix the cloud on the selected target, which becomes particularly difficult to obtain as soon as the size of the produced droplets reaches too low values. The problem of spraying is in this context focused on the definition of the minimum dimension of the cloud droplets according to the conditions imposed by the deposit to be realized, the nature of the culture to be treated, the atmospheric conditions of the moment, the quality of the pesticide to be spread and the material of treatment used.

It is logical to study the way of regulating the size of the cloud droplets produced with the various apparatuses before considering the other factors."

Dr. Jacky Ganry Chairman of the Section on Tropical and Subtropical Fruits

ISHS 


\section{Lu dans Fruits, il y a 50 ans...}

Deux articles de Fruits 12 (10) et (11) ont retenu notre attention.

\section{La Tristeza des agrumes}

Le premier document, d'A. Comelli, portait sur "La Tristeza des Citrus en Afrique équatoriale française (AEF)". Y sont relatés les tout premiers cas de Tristeza des agrumes détectés en Afrique centrale :

"En 1952, M. Pelegrin [Institut français de recherches sur les fruits tropicaux (IFAC)] dans son rapport de prospection sur l'AEF mentionnait la présence possible de la Tristeza dans la collection de Brazzaville et recommandait d'exécuter des tests avant de continuer à diffuser ces variétés. Nous savons maintenant qu'il était déjà trop tard.

En 1954, nous observions pour la première fois à Boko... un pomélo... atteint de Stem pitting...

En 1956, lors d'une seconde visite à Boko, nous rapportâmes des photos des symptômes observés qui furent identifiés comme répondant à la description du Stem pitting...

En juin 1957, nous avons observé chez un planteur d'arachides du Madingou des symptômes très nets de Tristeza sur plants de lime acide du pays...

Sur la Station de Loudima (IFAC) plusieurs plants de lime mexicaine présentant les mêmes symptômes à un stade plus accusé ont été observés récemment... Il semble donc bien prouvé que la Tristeza existe dans le Niari...

Il est d'ailleurs à craindre que le Cameroun ne soit également affecté, car les mêmes fausses carences ont été observées sur jeunes greffes à la Station de Nyombé (IFAC).

Enfin en Oubangui, nous avons observé des cas typiques de Stem pitting ...

... Au Tchad, des symptômes identiques aux fausses carences ont été observés... Ils sont de fortes présomptions de présence de Tristeza.

Une conséquence plus grave de cette situation est le danger qu'elle représente pour l'Afrique du Nord... malgré l'écran que représente le Sabara."

\section{La cercosporiose des bananiers}

Le deuxième article, de J. Cuillé et H. Guyot, portait sur "Le matériel de traitement, son utilisation ". Nous ne reprendrons que l'introduction qui replace cet article dans l'ensemble des travaux sur le contrôle de la cercosporiose des bananiers, qui ont marqué la vie de l'Institut français de recherches sur les fruits tropicaux :

"Nous avions montré dans un travail précédent que, lors de l'utilisation d'appareils à débit réduit, l'opérateur se trouvait placé devant deux données d'intérêt opposé:

- La confection d'un nuage pesticide composé de très petites particules permet d'atteindre une grande portée et d'assurer sur la feuille une excellente répartition du pesticide.

- La fixation du nuage sur la cible choisie devient particulièrement difficile à obtenir dès que la taille des gouttelettes produites atteint des valeurs trop faibles.

Le problème des traitements ainsi posé se réduit à la définition de la dimension minimum des gouttelettes d'un nuage en fonction des conditions imposées par le dépôt à réaliser, la nature de la culture à traiter, les conditions atmosphériques du moment, la qualité du pesticide à répandre et le matériel de traitement utilisé.

Il est logique d'étudier la façon de régler la taille des gouttelettes du nuage produit avec les différents appareils avant d'envisager les autres facteurs. "

Dr. Jacky Ganry

Président de la section Fruits tropicaux et subtropicaux 